\title{
Respiratory Health Risks of Limestone Factories' Dust: Gaza City as a Case Study
}

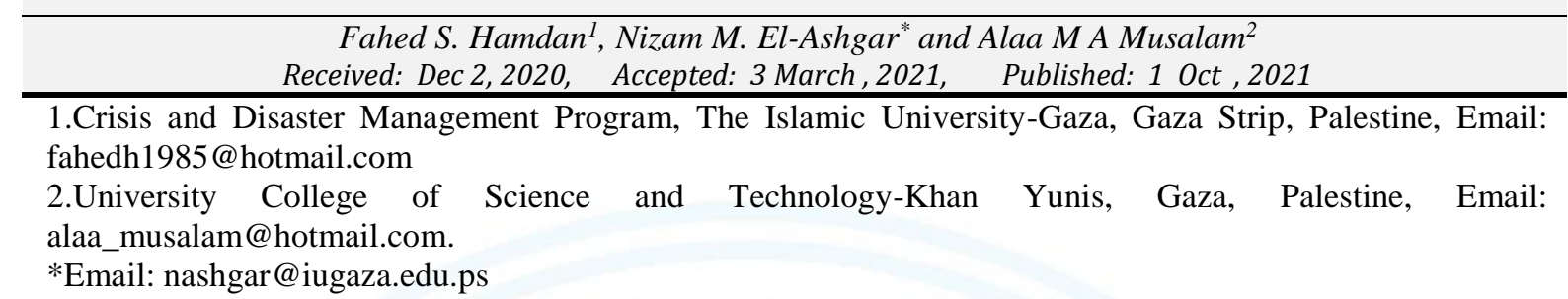

\section{Abstract}

Limestone-cutting is one of the most important industries in the Gaza Strip that uses natural stone, but it is also the most likely to cause dust emissions. This study aims to identify the respiratory health risks that affect the limestone-cutting workers and to identify factors related to the abnormal breathing among workers in marble workshops in the Gaza Strip, southern Palestine. Personal variables and their relationship to abnormal breathing were identified.

A cross-sectional study was conducted on (30) persons working in marble workshops in the Gaza Strip. The study data were collected using questionnaires and interviewing tools with the workers, as well as conducting some clinical tests to measure breathing.

The results of the study showed that workers' complaints of coughing, chest pain, and wheezing were 50\%, 30\%, and 26.7\%, respectively. Chi-square analysis measurement showed that the workers' personal variables such as working in or out of the workshop, age of workers, and the length of time the workers spend at work were the most important factors associated with the measurement of abnormal breathing among workers.

The study concluded that the prevalence percentage of abnormal breathing symptoms among workers who worked more than 10 years was 50\%, while for those who worked less than 10 years was $26.1 \%$. Also, there was no significant difference between smokers and non-smokers with regard to abnormal respiratory status, and the results were 64.7\% and $69.2 \%$ for smokers and non-smokers, respectively.

The study recommended taking the necessary precautions to maintain the safety of workers in places of rock cutting and improving the quality of ventilation by increasing the rates of air change.

Keywords: Spirometry, Abnormal breathing measurements, Quarries, Limestone-cutting, Air change rates. 


\section{Introduction}

Throughout history, people in Palestine have been using natural rocks in building and decorating houses, landmarks, and places of worship, e.g., Al-Aqsa Mosque, the Dome of the Rock, and the Church of the Nativity (S.Palestinian \& C.Marble, 2021) \& (S. Salem, 2021). Today, stone quarrying is considered as one of the key industrial activities contributing to the development of the national economy in Palestine. The share $5.5 \%$ of GDP) of this growing sector contributes annually with US 600 million dollars to the national wealth and benefiting around 25,000 employees and 1,124 stakeholder companies (S. Salem, 2021) \& (A.Thawabtah, 2017) . The number of establishments operating in the stone and marble sector in Palestine exceeds 1200 establishments, including factories, quarries, crushers, and small workshops (S.Palestinian \& C.Marble, 2021).

The raw material of stone, in particular, is available in feasible quantities, grades, and dimensions. These qualities attract local mining investors to open up large-scale production plants in the country. The most favorable sites for quarrying are known to be found in flat-topography territories, such as in the vicinity of the cities of Hebron, Bethlehem, and Nablus in the West Bank. The natural rock of limestone is extracted, processed, and produced in various dimensions and quantities, and then delivered to the market for construction and decoration applications (S. Salem, 2021).

Through the lifecycle of a stone quarry industry, wastes are generated in various forms, such as solid wastes and fluid/airborne wastes. Dust emissions are airborne particles resulting from quarrying and stone cutting operations such as blasting, drilling, crushing, hauling, cutting, polishing and decorating (S. Salem, 2021). These contaminants pollute the surrounding environment and impose serious health risks to workers and near-site users, including respiratory and pulmonary ailments, skin, and eye injuries (M. Elbayoumi et.al, 2020) \& (A.Mengeshe \& A. Bekel, 1998) \& (K.Elsalamoni et. al, 2018). The work of these quarries since ancient times is based on the use of marble, the construction of marble-like carving statues, buildings, and monuments. It is also used in internal tiles and floors. However, it is noteworthy to mention that the "marble" term involved in the "Stone and Marble Industry" (SMI) in Palestine is wrongly used, because this term is scientifically used for the metamorphic rock (marble) that is naturally generated under high pressures and temperatures, but not for the cut limestone rock excavated in Palestine 
(S. Salem, 2021). Therefore, Salem (2021) recommended that the SMI industry is to be correctly called "Limestone Industry (LSI)" (S. Salem, 2021). The formation of fine powder from the limestone marble cutting is one of the environmental problems worldwide (S. Salem, 2021) \& (V.Corinaldesi et. al., 2010). Site workers operating in quarries of all kinds of rocks are usually exposed to hazardous dosages of emitted dust in the ambient air. The dust is largely made of micro and nano-crystalline silica and/or carbonate particles that can be easily inhaled and ingested through human tissues (M. Elbayoumi et.al, 2020). The cutting rock dust affects human health with potential injuries, e.g. pulmonary diseases, silicosis toxicity, etc. The severity of the injury depends on a number of factors, including dust particle size, concentration level, and exposure duration (S. Salem, 2021) \& (El-Gammal, M.I., et al., 2011) \& (Kearey, P. 2001) \& (Pilkington, A., et al. 1996) \& (D.Oxman et. al., 2012). A number of occupational health studies from different world countries reported that chronic exposure to high concentrations of fine dust has been linked to developing disease symptoms in quarry workers (S. Salem, 2021). In Nigeria for example, fine dust generated from granite processing has caused lung disease symptoms among workers of both males and females (E.Urom et. al., 2004). In India, the prevalence rate of pulmonary tuberculosis, induced by marble quarry dust emissions, was higher for workers who had been working over 5 years in a confined environment without personal protection (P.Tomar et. al., 2014).

Article 16 of the Environment Law of 1999 stipulated the necessity of protecting the environment from quarry pollutants. As well as Article 17 of the Council of Ministers Resolution in 2010, stipulated the necessity of providing health and safety equipment in the workplace for workers and visitors from abroad, as well as providing fire extinguishers and noise reduction devices (S. Salem, 2021) \& (P.M.E 2010).

This study aims to determine the prevalence of respiratory problems among stone-cutting industry workers in the Gaza Strip, and to identify the most important factors related to the abnormal breathing among them. Personal variables such as working in or out of the workshop, age of workers, and the length of time the workers spend at work and work environments that correlated to abnormal breathing were also identified. 
The results of this study may contribute to the present knowledge of new insights into the current environmental health situation of the quarry industry in the Gaza Strip, Palestine. Recommendations for the improvements and future work were also projected based on the study findings.

\section{Materials and Methods}

\subsection{Study Tools}

The commercially available software of Statistical Package for Social Sciences (SPSS) version 25 was used for data processing and representation.

The participants of the study sample were interviewed using a self-drafted questionnaire designed by researchers in order to formulate basic knowledge on the socio-demographic characteristics, work history, pulmonary function test (spirometry) using a spirometer, which belongs to the Ministry of Health (Occupational Health Department). Spirometry was performed by a trained researcher using a spirometer (Spirovit SP-1, Schiller America, Doral, FL) and standard procedures were followed (L.Enright et. al. 1991).

The questionnaire constitutes of two parts; the first part contains the health characteristics data of the study sample, and the second part contains the workplace characteristics data of the study sample. The validity and reliability of the questionnaire were examined by experts' review and editing have been done according to their comments.

The test procedure was explained to the participants and instructions were given to them. The participants sat quietly for 10 minutes and allowed to become mentally and physically comfortable before the test. The best forced expiratory volume in one second (FEV1) and the forced vital capacity (FVC) were recorded, then the FEV1/ FVC ratio was calculated. The results were printed automatically according to the diagnostic criteria: through the results of the Spirometry: a- Normal (free), b-abnormal.

\subsection{Study Design and Scope}

In this study, a cross-sectional methodology with analytical components was used in observing and evaluating the correlation of the socio-demographic factors of the limestonecutting workers in the Gaza Strip, sourthen Palestine, during continuous exposure to the dust of the quarry factories and the abnormality of their pulmonary system. 
Continuous variables were expressed as mean and standard deviation. Categorical variables were expressed as frequencies and percentages. The Chi-square was used to study the relationship between categorical variables.

\subsection{Study Setting}

Due to the small number of establishments operating in the Gaza Strip, and the difficulty of accessing the study sample because of the lack of official statistics about this profession, the researchers took a random sample of these establishments with a number (7) where employees in these establishments have the same geographical, climatic, social and economic conditions, and they use the same machines and tools. The seven limestonecutting establishments that have been studied are in the Gaza Governorate, where from each quarry 4-5 respondents were targeted.

\subsection{Study Sample and Period}

The study sample consisted of 30 employees working in limestone-cutting operations and administrative positions.

The study was conducted over a 70-day period; from the July 1st to September 10th 2019. July was chosen because, during this period of the year, the industrial activities at quarry sites are usually intensified.

\section{Results}

The health characteristics data of the study sample versus the personal parameters of the quarry workers are given in Table 1. It is obvious from Table (1) that the mean age of the participants in the study sample is 33 years, and $93.3 \%$ of the participants are married. The results also revealed that the average of studying years (post-secondary education) for the participants is 11.8 years. The study sample composed of non-smoking participants (43.3\%) and smoking participants (56.7\%), with 6.96 years as an average smoking period. Among the smoking participants, it was found that the number of cigarettes for smokers is 7.63 cig per day and that only $13.3 \%$ are carrying out a periodic examination of the breathing status. It is also observed that $43.3 \%$ of the participants suffers from problems, such coughing, chest pain, and wheezing and 4.73 is the average number of health 


\section{ISRAA UNIVERSITY JOURNAL OF APPLIED SCIENCE}

\section{Volume 5 :Issue1, October, 2021}

problems experienced by the study participants that are not helping in pointing to the real factors responsible for the deteriorating health conditions of the workers.

The analysis also indicated that $50 \%$ of the participants shows coughing symptoms ranging from high $(16.7 \%)$, intermediate $(10.0 \%)$ and low $(23.3 \%)$ severity. The average period of coughing is 5.24 years. Only $23.3 \%$ of the participants claimed they received respiratory treatment during their job life. The results also revealed that $30 \%$ of the study sample suffers from chest pain, and $16.7 \%$ of the participants suffers from moderate chest pain. Moreover, the results revealed that $26.7 \%$ of the participants have a wheeze in the chest, and $16.7 \%$ of the participants have moderate wheeze in the chest.

Table 1: Health Characteristics Data of the Study Sample

\begin{tabular}{|c|c|c|c|}
\hline \multicolumn{2}{|r|}{ Characteristics } & Value & Percentage (\%) \\
\hline \multirow{3}{*}{ Age (in Years) } & Less than 45 & 24 & 80.0 \\
\hline & More than 45 & 6 & 20.0 \\
\hline & $\operatorname{Mean}(\bar{x} \pm \mathrm{SD})$ & \multicolumn{2}{|c|}{$33 \pm 7.83$} \\
\hline \multicolumn{2}{|l|}{$\begin{array}{l}\text { Marital status: } \\
\text { Single } \\
\text { Married }\end{array}$} & $\begin{array}{c}2 \\
28\end{array}$ & $\begin{array}{c}6.7 \\
93.3\end{array}$ \\
\hline \multicolumn{2}{|c|}{ Education level (in Years) $($ mean \pm SD) } & \multicolumn{2}{|c|}{$11.8 \pm 2.42$} \\
\hline \multirow{4}{*}{ Smoking habits } & Non-Smoking & 13 & $43.3 \%$ \\
\hline & Smoking & 17 & $56.6 \%$ \\
\hline & No. of Years Smoking $(\bar{x} \pm$ SD $)$ & \multicolumn{2}{|c|}{$6.96 \pm 7.87$} \\
\hline & $\begin{array}{l}\text { No. of Smoked Cigarettes per } \\
\text { day }(\bar{x} \pm \mathrm{SD})\end{array}$ & \multicolumn{2}{|c|}{$7.63 \pm 8.47$} \\
\hline \multicolumn{2}{|c|}{$\begin{array}{l}\text { Yes } \\
\text { No }\end{array}$} & $\begin{array}{c}4 \\
26 \\
\end{array}$ & $\begin{array}{l}13.3 \\
86.7\end{array}$ \\
\hline \multicolumn{2}{|c|}{$\begin{array}{l}\text { A healthy problem from work: } \\
\text { Yes }\end{array}$} & $\begin{array}{l}13 \\
17\end{array}$ & $\begin{array}{l}43.3 \\
56.7\end{array}$ \\
\hline \multicolumn{2}{|c|}{$\begin{array}{l}\text { No } \\
\text { Number of healthy malaise (mean } \pm \text { SD) }\end{array}$} & \multicolumn{2}{|c|}{$4.73 \pm 7.87$} \\
\hline \multicolumn{2}{|c|}{$\begin{array}{l}\text { Receiving respiratory treatment: } \\
\text { Yes }\end{array}$} & $\begin{array}{c}7 \\
23 \\
\end{array}$ & $\begin{array}{l}23.3 \\
76.7\end{array}$ \\
\hline $\begin{array}{l}\text { Coughing symptt } \\
\text { Yes } \\
\text { No }\end{array}$ & & $\begin{array}{l}15 \\
15\end{array}$ & $\begin{array}{l}50.0 \\
50.0\end{array}$ \\
\hline $\begin{array}{l}\text { Cough intensity: } \\
\text { High } \\
\text { Intermediate } \\
\text { Low }\end{array}$ & & $\begin{array}{l}5 \\
3 \\
7\end{array}$ & $\begin{array}{l}16.7 \\
10.0 \\
23.3\end{array}$ \\
\hline \multicolumn{2}{|c|}{ Duration of cough (mean \pm SD) } & \multicolumn{2}{|c|}{$5.24 \pm 5.19$} \\
\hline \multicolumn{2}{|c|}{$\begin{array}{l}\text { Pain in chest: } \\
\text { Yes } \\
\text { No }\end{array}$} & $\begin{array}{c}9 \\
21\end{array}$ & $\begin{array}{l}30.0 \\
70.0\end{array}$ \\
\hline \multicolumn{2}{|c|}{$\begin{array}{l}\text { High } \\
\text { Intermediate } \\
\text { Low }\end{array}$} & $\begin{array}{l}2 \\
5 \\
2\end{array}$ & $\begin{array}{c}6.7 \\
16.7 \\
6.7\end{array}$ \\
\hline \multicolumn{2}{|c|}{ Duration of chest pain $($ mean \pm SD) } & \multicolumn{2}{|c|}{$0.6 \pm 1.01$} \\
\hline
\end{tabular}




\begin{tabular}{|l|c|c|}
\hline Wheezes in chest: & 8 & 26.7 \\
Yes & 22 & 73.3 \\
\hline No & & \\
\hline Severity of wheezes: & 2 & 6.7 \\
High & 5 & 16.7 \\
Intermediate & 1 & 3.3 \\
\hline Low & & \\
\hline
\end{tabular}

Table (2) shows that most of the study's participants are employed in limestone-cutting (80\%), while $20 \%$ are office-based employees. The average working years is 11.07 years.

The results also showed that the average number of working hours is 8.9 hours per day, and $33.3 \%$ of the participants wearing a mask at work, while $66.7 \%$ do not wear a mask at work. Regarding the type of mask worn by employees during work, $23.3 \%$ wear a mask with an air filter.

From the view point of participants, the results showed that $93.3 \%$ of the workplaces have good ventilation (depending on the rate of change of air in the place), while $6.7 \%$ do not have good ventilation. Regarding the presence of suction devices in the place, it was found that $43.3 \%$ have air suction devices, while $56.7 \%$ do not have air suction devices. It also was found that $83.3 \%$ of the investigated factories provide protective masks during work.

Table 2: Workplace Characteristics Data of the Study Sample

\begin{tabular}{|c|c|c|}
\hline Working Conditions & Value & Percentage (\%) \\
\hline $\begin{array}{l}\text { Working environment: } \\
\text { indoor: } \\
\text { outdoor: }\end{array}$ & $\begin{array}{l}24 \\
6\end{array}$ & $\begin{array}{l}80.0 \\
20.0\end{array}$ \\
\hline Duration of work in years $($ mean \pm SD) & $11 . \cdot V \pm \Upsilon, \cdot\urcorner$ & \\
\hline Working hours (mean \pm SD) & $8.90 \pm 2.17$ & \\
\hline $\begin{array}{l}\text { Wearing a mask: } \\
\text { Yes } \\
\text { No }\end{array}$ & $\begin{array}{l}10 \\
20\end{array}$ & $\begin{array}{l}33.3 \\
66.7\end{array}$ \\
\hline $\begin{array}{l}\text { Type of mask: } \\
\text { No using } \\
\text { Surgical mask } \\
\text { Air filter mask }\end{array}$ & $\begin{array}{l}21 \\
2 \\
7\end{array}$ & $\begin{array}{l}70.0 \\
6.7 \\
23.3\end{array}$ \\
\hline $\begin{array}{l}\text { Adhering to the conditions of ventilation in the } \\
\text { workplace: } \\
\text { Yes } \\
\text { No }\end{array}$ & $\begin{array}{l}28 \\
2\end{array}$ & $\begin{array}{l}93.3 \\
6.7\end{array}$ \\
\hline $\begin{array}{l}\text { Presence of suction devices in place: } \\
\text { Yes } \\
\text { No }\end{array}$ & $\begin{array}{l}13 \\
17\end{array}$ & $\begin{array}{l}43.3 \\
56.7\end{array}$ \\
\hline The workplace provide protective masks: & & \\
\hline
\end{tabular}




\begin{tabular}{|l|l|l|}
\hline Yes & 25 & 83.3 \\
No & 5 & 16.7 \\
\hline
\end{tabular}

Table (3) shows the relationship between different risk factors and abnormal breathing results of workers. There is no significant difference between smokers and non-smokers with regard to the abnormal breathing status. The results are $64.7 \%$ and $69.2 \%$ for smokers and non-smokers respectively, with a level of significance of 0.794 . Regarding the nature of work, $26.1 \%$ of participants suffered from abnormal breathing status of those working inside, while $66.7 \%$ suffers from abnormal breathing status who are managers and other technicians, but this difference is not statistically significant $(\mathrm{p}=0.063)$.

The prevalence of abnormal breathing symptoms among workers employed more than 10 years is $(50 \%)$, while for those who worked for less than 10 years it is $(26.1 \%)$ at $(\mathrm{p}=$ $0.018)$.

Regarding the educational status, a large percentage of the abnormal breathing status is for workers with a school level of $(41.7 \%)$, but this difference is not statistically significant (p $=0.053)$.

Table 3: Analysis of Spirometry Testing Results of the Study Sample

\begin{tabular}{|c|c|c|c|c|c|}
\hline \multirow{2}{*}{ Sample's Characteristics } & \multicolumn{2}{|c|}{ Abnormal Breathing } & \multicolumn{2}{|c|}{ Normal Breathing } & \multirow{2}{*}{ p-value } \\
\hline & $\mathbf{N}$ & $\%$ & $\mathbf{N}$ & $\%$ & \\
\hline $\begin{array}{l}\text { Smoking status } \\
\text { Smoking } \\
\text { Non-Smoking }\end{array}$ & $\begin{array}{l}6 \\
4\end{array}$ & $\begin{array}{l}35.3 \% \\
30.8 \%\end{array}$ & $\begin{array}{c}11 \\
9\end{array}$ & $\begin{array}{l}64.7 \% \\
69.2 \%\end{array}$ & 0.794 \\
\hline $\begin{array}{l}\text { Education category } \\
\text { School level } \\
\text { University level }\end{array}$ & $\begin{array}{c}10 \\
0\end{array}$ & $\begin{array}{l}41.7 \% \\
0.00 \%\end{array}$ & $\begin{array}{c}14 \\
6\end{array}$ & $\begin{array}{c}58.3 \% \\
100.0 \%\end{array}$ & 0.053 \\
\hline $\begin{array}{l}\text { Age category } \\
\text { Less than } 45 \text { years } \\
45 \text { years and more }\end{array}$ & $\begin{array}{l}4 \\
6\end{array}$ & $\begin{array}{c}16.7 \% \\
100.0 \%\end{array}$ & $\begin{array}{c}20 \\
0\end{array}$ & $\begin{array}{l}83.3 \% \\
100.0 \%\end{array}$ & $0.000 * *$ \\
\hline $\begin{array}{l}\text { Type of work } \\
\text { Worker inside } \\
\text { Management/others }\end{array}$ & $\begin{array}{l}6 \\
4\end{array}$ & $\begin{array}{l}26.1 \% \\
66.7 \%\end{array}$ & $\begin{array}{c}17 \\
2\end{array}$ & $\begin{array}{l}73.9 \% \\
33.3 \%\end{array}$ & 0.063 \\
\hline $\begin{array}{l}\text { Duration of work: } \\
\text { less than } 10\end{array}$ & $\begin{array}{l}1 \\
9\end{array}$ & $\begin{array}{c}8.3 \% \\
50.0 \%\end{array}$ & $\begin{array}{c}11 \\
9\end{array}$ & $\begin{array}{l}91.7 \% \\
50.0 \%\end{array}$ & $0.018 * *$ \\
\hline
\end{tabular}


ISRAA UNIVERSITY JOURNAL OF APPLIED SCIENCE

\begin{tabular}{|l|c|c|c|c|c|}
\hline more than 10 & & & & & \\
\hline Type of mask & & & & & \\
Nothing & 6 & $30.0 \%$ & 14 & $70.0 \%$ & 0.434 \\
Surgical mask & 2 & $66.7 \%$ & 1 & $33.3 \%$ & \\
Air filter mask & 2 & $28.6 \%$ & 5 & $71.4 \%$ & \\
\hline Marital status & 0 & $0.00 \%$ & 0 & $100.0 \%$ & 0.301 \\
Single & 10 & $35.7 \%$ & 18 & $64.3 \%$ & \\
Married & 0 & & & & \\
Wearing a mask & 10 & $50.0 \%$ & 10 & $50.0 \%$ & \\
Yes & & & & & \\
No & & & & & \\
\hline
\end{tabular}

** At the significance level (0.05)

\section{Discussion}

This study attempted to assess the risk factors that affect the breathing status of limestone-cutting workers by linking the breathing state to the personal and functional factors of the study sample.

The average working hours are 8.9 hours, which indicates that workers are at high risk of inhalation of dust from rock cutting, during their work for more than the allowed work hours ( 8 hours/day). Moreover, $80 \%$ of the participants in this study have a school level and only $20 \%$ are university graduates, which indicates a low level of awareness of respondents about the health impact of dust from rock cutting. The current study showed that the prevalence of cough among the participants is $50 \%$, chest pain is $30 \%$, and chest wheezing is $26.7 \%$. These values are compatible with the study of El-Salamoni, et al., 2015, which found the prevalence of breathing complaints $28.2 \%$, chest pain 17.8\%, and chest wheezing 3.8\%. This finding differed from the study of Aghilinejad et al. 2006, which found that a chronic cough in respondents (75\%).

The study found that the age is one of the important factors in determining abnormal breathing, where the results proved that (100\%) of workers over (45) years of age suffer from abnormal breathing status. This result is different from the result of Nwibo, et al., 2012, which found no relationship between pulmonary function and age among stone cutting workers.

Of all the 30 participants, 26 are working inside the stone-cutting site, so they are susceptible to dust from the stone cutting. The other 4 participants are working outside the cutting sites and they are administrators and technicians. This indicates that most of the participants in the stone-cutting 
facilities are at risk of inhalation of dust from stone-cutting. However, there is no significant difference between stone-cutting site and out-of-site staff with regard to breathing problems. This finding contradicts the finding of Subhashini and Satchidhanandam that workers close to stone cutting are more likely to have breathing health problems.

This study proved that wearing the mask during work is an important factor in the abnormal breathing state, as all participants who wear the mask do not have an abnormal breathing condition, while $50 \%$ of the participants who do not wear a mask at work suffer from abnormal breathing condition (Table 3). This finding is similar to Halwenge study (Halwenge J.A. 2015), which found that only $22 \%$ of respondents wore dust-proof equipment such as clothing and masks, but it differs on that protective equipment was not an important factor in identifying workers' breathing problems in rock cutting.

The study found that smoking is not an important factor in the abnormal breathing status of stonecutting workers; where $35.3 \%$ have an abnormal breathing condition of smokers, compared to $30.8 \%$ have an abnormal breathing status of non-smokers. In their study, Ghotkar et al. 1995 found that there is no significant difference between the pulmonary function averages of male smokers and non - smokers.

While this result is different from the study of El-Salamoni et al.2015, which found that smoking is an important factor in reducing respiratory function where $24.5 \%$ of smokers had abnormal lung function compared to $17.3 \%$ of non-smokers who suffer from abnormal lung function.

\section{Conclusion}

In this study, it was clear that the prevalence of abnormal breathing symptoms among workers in limestone-cutting facilities in the Gaza Strip, who have worked for more than 10 years was 50\%, and, thus, predominated, while for those who have worked for less than 10 years was $26.1 \%$. There was no significant difference between smokers and non-smokers with regard to abnormal breathing status, and the results were $64.7 \%$ and $69.2 \%$ for smokers and non-smokers, respectively. 
The study recommended the need to take precautions for the stone-industry workers by wearing personal protective equipment such as masks and improving ventilation quality at the rock cutting facilities or factories by increasing air change rates. The study also recommended the need to provide legal legislation governing the work in such institutions to protect workers.

\section{Acknowledgement}

The authors highly appreciate the efforts of the Islamic University-Gaza for facilitating the accomplishment of this study. 
ISRAA UNIVERSITY JOURNAL OF APPLIED SCIENCE

Volume 5 :Issue1, October, 2021

ISSN: 2523-0522

\section{References}

Aghilinejad, M., Jamamati, M.R. and Farshad, A.A. (2006). Prevalence of Silicosis among workers in stone-cutter and Silica Powder Production Factories". Tanaffos, 5(3), 3136.

Corinaldesi, V., Moriconi, G. and Naik, T.R. (2010). Characterization of marble powder for its use in mortar and concrete". Construction and building materials, 24 (1), 113-117.

Elbayoumi, M. (2017). Concentrations Indoor Air Pollutants Influenced By Dust Storm Event In Selected Schools In Gaza Strip. Israa University Journal Of Applied Science (IUJAS), 1, 43 -54

El-Gammal, M.I., et al. (2011). Health risk assessment of marble dust at marble workshops". Nature and Science, 9, 11. 144-154.

EL-SALAMONI, O.K., IBRAHIM, H.M. and EL-DIN, W.S. (2015). Pulmonary Problems among Stone Cutting Workers in West Bank-Palestine". The Medical Journal of Cairo University, 83(1), 769-775.

Enright, P.L., Johnson, L.R., Connett, J.E., Voelker, H. and Buist, A.S. (1991). Spirometry in the lung health study. The American review of respiratory disease, 143, 1215-1223.

Ghotkar, V.B., Maldhure B.R. and Zodpey, S.P. (1995). Involvement of lung and lung function tests in stone quarry workers. Indian Journal of Tuberculosis, 42, 155-60.

Halwenge J.A. (2015). Dust Pollution and Its Health Risks among Rock Quarry Workersin Kajiado County. PhD Thesis. Kenyatta University, Kenya.

Kearey, P. (2001). Dictionary of Geology, $2^{\text {nd }}$ ed. Penguin Group, London (United Kingdom).

Mengesha, Y.A. and Bekele, A. (1998). Relative chronic effects of different occupational dusts on respiratory indices and health of workers in three Ethiopian factories. American journal of industrial medicine, 34 (4), 373-380.

Nwibo, A.N., Ugwuja, E.I., Nwambeke, N.O., Emelumadu, O.F. and Ogbonnaya, L.U. "Pulmonary problems among quarry workers of stone crushing industrial site at Umuoghara, Ebonyi State, Nigeria". The International Journal of Occupational and Environmental Medicine, 3 no. 4 (2012): 178-85.

Oxman, A.D., Muir, D.C., Shannon, H.S., Stock, S.R., Hnizdo, E. and Lange, H.J. (2012). Occupational dust exposure and chronic obstructive pulmonary disease: a systematic overview of the evidence. American Review of Respiratory Disease, 148 (1), 38-48. 
Palestinian Ministry of Environment (2010). Environmental law and set of regulations and $\begin{array}{lllll}\text { instructions. } & \text { [Accessed: } & 4 & \text { April }\end{array}$ http://environment.pna.ps/ar/files/Law\%20No7_environmental\%20regulation.pdf

Palestinian Stone \& Marble Center (Online). Historical Overview. Palestine polytechnic University, Palestine. [Accessed: 4 A pril2021]. Available at: https://psmc.ppu.edu/en/resource/historicaloverview.

Pilkington, A., et al. (1996). Scientific Opinion on the Health Effects of Airborne Crystalline Silica". Edinburgh (UK): Institute of Occupational Medicine. IOM report TM/95/08.

Salem, H.S. (2021). Evaluation of the Stone and Marble Industry in Palestine: environmental, geological, health, socioeconomic, cultural, and legal perspectives, in view of sustainable development". Environmental Science and Pollution Research 1-23.

Subhashini, A.S. and Satchidhanandam, N.A.T.E.S.A. "Maximal expiratory flow volume curve in quarry workers". Indian journal of physiology and pharmacology, 46(1), 78-84.

Thawabtah , A. (2017). The impact of internal and external obstacles on the development of stone and marble sector in Palestine". Unpublished PhD Thesis, AL-Quds University, Gaza, Palestine.

Tomar, S.P., Kushwah, A.P., Pande, S. and Baghel, P.S. (2014). A comparative study of pulmonary Koch's among marble stone worker community of Bhedaghat and nonmarble stone worker community of Garha". International Journal of Medicine and Public Health, 4(4), 426-9.

Urom, S.E., Antai, A.B and Osim, E.E. (2004). Symptoms and lung function values in Nigerian men and women exposed to dust generated from crushing of granite rocks in Calabar, Nigeria". Nigerian Journal of Physiological Sciences, 19(1), 41-47.. 